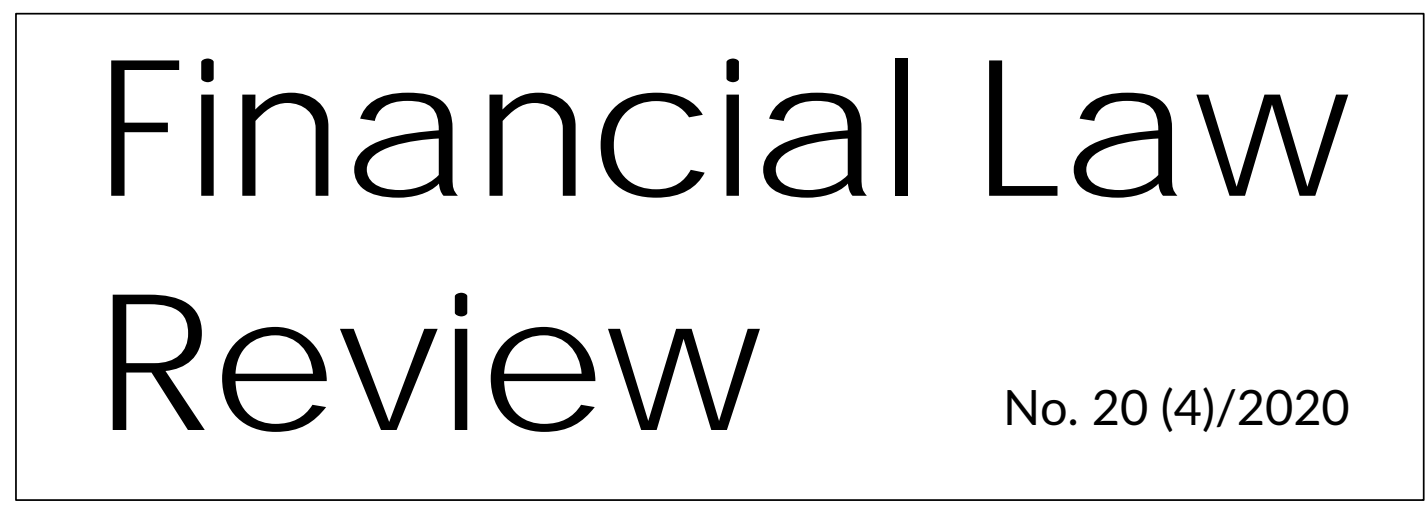

UNIVERSITY OF GDAŃSK • MASARYK UNIVERSITY • PAVEL JOZEF ŠAFÁRIK UNIVERSITY • UNIVERSITY OF VORONEZH http://www.ejoumals.eu/FLR

\title{
SUSTAINABLE FINANCE INITIATIVES AND THEIR IMPACT ON FINANCIAL STABILITY
}

\begin{abstract}
The article discusses the potential impact of sustainable finance initiatives on financial stability. A careful literature review on the subject of sustainable development and stability of the financial sector is performed in order to identify potential gaps in policies and regulations. Existing considerations around the impact of sustainable development efforts focus exclusively on the consequences of climate change for the portfolio of assets held by the financial sector, whereas the author examines the growing market for sustainable financial instruments as a potential threat. The results indicate that sustainability features of new financial instruments are not methodically evaluated in the context of their credibility and may therefore suffer from sudden loss of value that is not accounted for under the existing supervisory mechanisms. Inconsistent definitions and no single perception of sustainability further enhance the risk for investors and issuers and that risk needs to be accounted for under the mechanisms safeguarding financial stability.
\end{abstract}

Key words: sustainable development, sustainable finance, green bonds, capital requirements, financial stability.

JEL Classification: G18, G28, O13, Q01, Q53

\footnotetext{
* Assistant Professor, Department of International Business and Trade, Faculty of Economics and Sociology, University of Lodz, Poland. Author specializes in financial supervision in the European Union and financial stability. She is an author of many reviewed articles in academic journals. Contact email: klaudia.zielinska@uni.lodz.pl, https://orcid.org/0000-0003-3738-0468.
} 


\section{Introduction}

The subject of sustainability in finance has dominated the discussions about the future of finance in most developed countries around the world. Investments marketed as sustainable have gained popularity and different measures aiming to further enhance this demand have been proposed at a regulatory and political level. The aim of this article is to discuss the trends in sustainable finance and their potential impact they may have on financial stability.

The impact of sustainable development-related policy measures on financial stability has so far been analysed only in the context of climate change, where financial institutions could be affected through the insolvency of the borrowers, who's businesses would either be shut down, or no longer economically viable. The author proposes to broaden the related analysis onto the new sustainable financial instruments, the market for which has started growing at an impressive pace as of 2017. The author argues that excess demand for sustainable bonds, loans and other products can have a negative impact on the quality of instruments offered. If sustainability features are questioned and cannot be proved, entire tranches of such instruments can immediately lose value. The author also notes that standard credit ratings do not factor in such credibility risk properly and therefore the associated exposure can be underestimated, impacting the loss absorbing capacity of credit institutions, both as issuers and as investors.

In order to verify the potential impact of sustainable financial products on financial stability, the author presents a careful literature review that discusses the challenges associated with sustainable finance. First, the concept of sustainable development is defined and discussed. Then the process of including environmental, social and governance considerations in business practices of financial institutions is described. Third section provides a definition of financial stability and outlines the required capital structure of credit institutions. That section is followed by an analysis of future developments of sustainable financial instruments and their potential consequences for the performance of financial institutions. Finally, conclusions are presented, summarizing the key finding s and emphasizing the need to further streamline taxonomy on sustainable development beyond its environmental aspects and to enhance supervision over sustainable investment instruments.

\section{Sustainable development}


The subject of sustainable development has first been explicitly mentioned and discussed in a report prepared for the United Nation's (UN) General Assembly in 1987. It has been described as development that "(...) meets the needs of the present without the compromising the ability of future generations to meet their own needs" [The World Commission on Environment and Development, 1987: 16]. The report essentially called for coordination between economic growth and environment-preserving measures. As rightly noted by Emas [2015: 1-2] this concept has been raised before in A. Pigou's "Economics of Welfare", where the author discussed the problem of external costs caused by different economic activities, that are borne by the society through damage to public goods (e.g. clean water, non-polluted air) without affecting the economic performance of the causer. This problem is often referred to as "market failure" since the polluting companies are not being held accountable for the damage to the environment caused, yet the author would argue that this situation is largely a result of consumer's preference, where the demand was, and often still is most elastic towards the price of goods and is rarely directly affected by the polluting activity. As the consumers become more concerned about the impact on environment, the demand function for different goods is evolving, proving that in fact the market is capable of performing its functions well. The speed of this shift depends more on education, public awareness-raising initiatives and availability of products allowing consumers to show their preference, rather than the stage of market development or its liquidity.

A useful overview of the most relevant high-level documents on the interactions between economic development and environmental impact that followed the 1987 General Assembly can be found in Klarin [2018: 67-94]. Out of the more interesting documents from the perspective of this article is the UN's 2030 Agenda for Sustainable Development [United Nations 2015: 1-35]. It includes seventeen Sustainable Development Goals (SDGs), that view this process in three aspects [Schoenmaker, Schramade 2019: 14-15]:

- $\quad$ social (e.g. ending poverty and hunger, ensuring access to healthcare and education);

- $\quad$ economic (e.g. sustainable consumption and production, reducing inequalities within and between countries);

- $\quad$ environmental (e.g. tackling climate change, sustainable use of forests and marine resources).

These goals indicate the aspects that need to be considered when discussing the concept of sustainable development. They indicate that sustainability entails more than merely protecting the environment and reducing the use of natural resources and fossil fuels. 
Over the years, different definitions of sustainable development have been proposed, often with the aim to narrow down the scope of the original definition of 1987. As indicated by Toman [1999: 3-6], the definition from report to the United Nations in principle allows damaging the environment as long as they can be compensated through different investment that enshrine the interests of future generations. This feature constitutes the division between "weak" and "strong" definitions of sustainability - first assumes that different forms of capital i.e. natural and man-made can replace each other, while the other clearly states that natural goods are irreplaceable [Barua, Khataniar 2016: 4-7].

Regardless of the preferred approach, the subject of sustainability has started affecting different branches of the economy, where the social and political pressures have induced the inclusion of environmental considerations in corporate policies. In many aspects this has taken the form of preparing Corporate Social Responsibility (CSR) reports that typically considered an organization's impact on environment and society [Hys, Hawrysz 2012: 1515-1524]. A study by P. Smith and C. Sharicz [2011: 73-86] provides evidence that many of the existing sustainability-driven corporate initiatives are still largely focused on the short-term and often misinterpret sustainable development as an attempt to reduce carbon footprint. The study concludes that the current situation can be largely attributed to the fact that there is no commonly accepted definition of sustainability that can be referred to. Nonetheless, the author believes that even the "quick-fix" approach proposed by most contemporary corporations can be seen as a step in the right direction on the path to sustainability. With no holistic definition available, these initiatives support gradual inclusion of the previously externalized costs in the business models, ensuring a less distortive transition towards a "greener" economy.

\section{Sustainable development in finance}

The concept of sustainability has also affected the world of finance, where financial institutions have started considering their potential contribution towards reaching the Sustainable Development Goals. Considering the role that the financial system plays in a modern economy, it is safe to state that these institutions are well placed to foster the transition towards sustainable economy through e.g. ensuring preferential access to financing, or conditioning access to funds on specific, SDG-linked criteria. More importantly though, the central position of financial institutions allows them to deliver on SDGs in all three aspects i.e. economic, social and environmental. These features of the 
financial system have put them at the centre of attention in the context of transition towards sustainable economy [Zorlu 2018: 1-24].

Early steps in sustainable development in finance were similar to those in other sectors, where related considerations were laid down in CSR reports, without going far beyond declaring support to the local communities and/or supporting environmental initiatives [Strandberg,2005: 1-52]. Sustainability in the financial world (both academic and business) was often considered in terms of long-term financing and liquidity management [De França, Sandoval 2019: 85-96; Attenbourgh 2009: 1-8]. In contrast, A. Soppe [2009: 1323] has identified finding the link between finance and corporate policies as a direct goal of research on sustainable finance. The author agrees that such aim definition serves its purpose and addresses the commonly-raised issue of detachment between corporate commitments and business practices [Dörry, Schulz 2018: 717-733; Urban, Wojcik 2019: 1-23].

It is important to highlight European Union's efforts in terms of streamlining taxonomy around sustainable finance. The June 2019 technical report on taxonomy prepared by an expert group on sustainable finance offers the much needed harmonisation in terms of definitions and screening of the impact of different sustainable investments [Expert Group on Sustainable Finance 2019]. The author notes, however, that the report so far addresses only the environmental aspects of development for which a taxonomy alignment percentage can be calculated and disclosed.

When it comes to the commitments of financial institutions, they can take different forms and relate to disclosure of additional information [Task Force on Climate-Related Financial Disclosures 2019: 1-135] refusal to finance polluting technologies [Buckley 2019: 1-34] or declaring financial support to sustainable investments [European Banking Federation 2017: 1-41]. The latter can take the form of direct lending, but also creating investment opportunities and asset management services [Pinchot, Christianson 2019]. While general policy-related commitments primarily put the company's reputation at stake, growing interest in sustainable investment have increased the risk of diluting the quality of the instruments issued. This risk is often referred to as greenwashing - practice of marketing the environmental features of different securities without sufficient evidence to be making such claims [International Finance Corporation, Climate Bonds Initiative 2018: 16]. In order to address this risk, the UN has encouraged the creation of an initiative called Principles for Responsible Investment (PRI) that was to promote the inclusion of environmental, social and governance-related (ESG) considerations in the investment decision-taking process. It is easy to see that PRI is largely aligned with UN's SDGs. The PRI has been established 
already back in 2006 and the growth of its signatories and of the size of assets they control over the years provide a good proxy of the existing and potential market size for sustainable investment (see graph 1 below).

\section{Graph 1. Signatories to the UN's PRI}

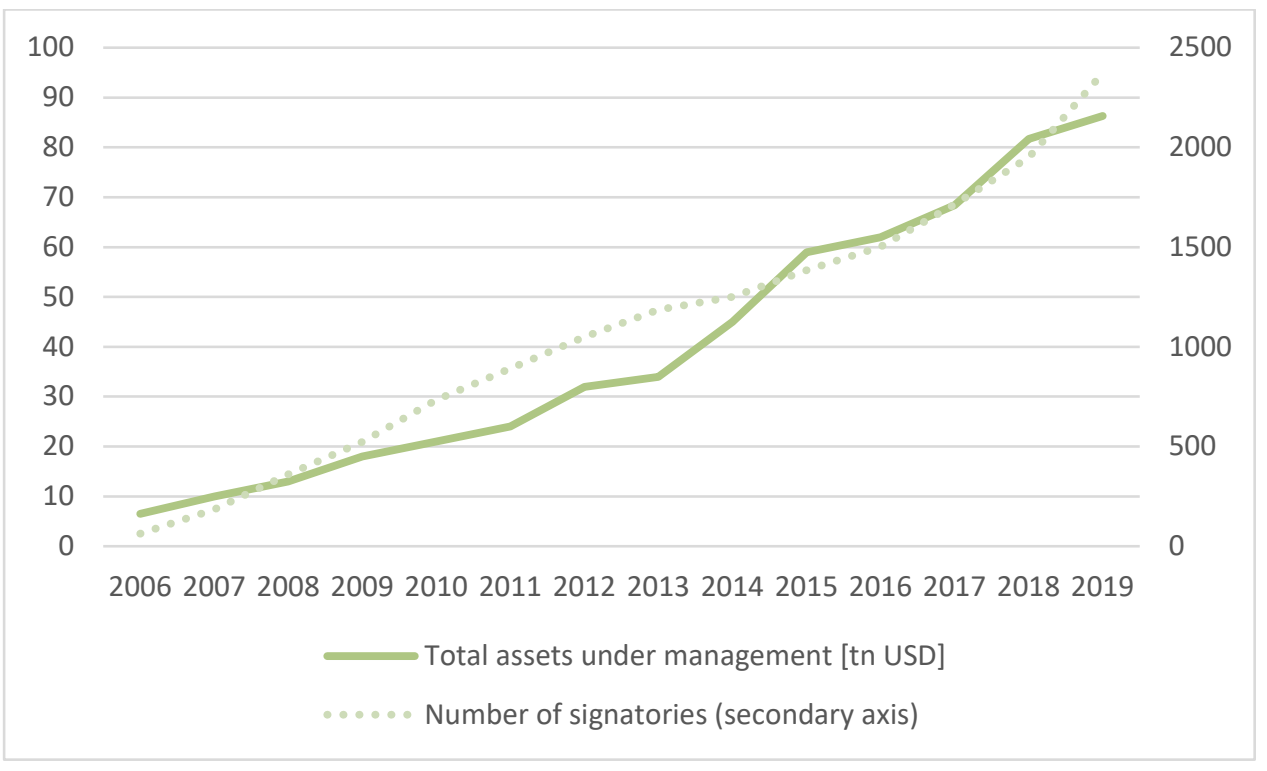

Source: Principles for Responsible Investment [2019].

With major international investors and asset owners as signatories to the PRI, the initiative controls an impressive portfolio of assets, the value of which was closing down to 90 trillion USD in 2019. This would suggest that the desired shift towards sustainability has largely taken place, yet, as highlighted by Urban and Wojcik [2019: 1-23], this is not quite the case. They prove that most banks that declare pursuing a sustainable development agenda in fact continue offering services to business that e.g. damage the environment or violate human rights. Proper quantification of the scale of such proceedings is an onerous task particularly due to no single definition of sustainable development and the author notes that this falls beyond the focus of this article.

Further analysis of the intersection between sustainable finance and stability of the financial system requires narrowing down its scope. This can be easily justified by the fact that, as just argued, commitments from financial institutions do not necessarily translate into concrete actions and therefore it is hard to state whether these can have any impact on stability at all. It is also hard to argue that investments that can be treated as sustainable bear different risks than typical businesses, yet this can be the case for demand-driven 
financial products, the value of which is largely defined by their "sustainability" feature. These relate particularly to instruments promoting sustainable development, such as:

- $\quad$ sustainable bonds;

- $\quad$ equity shares of entities promoting sustainable development;

- $\quad$ sustainability loans.

Credibility of such instruments as sustainable development-financing largely determines their value and liquidity and therefore exposes financial institutions to a risk of sudden loss of value, affecting entire product portfolios. Consequently, it also limits the treatment of these instruments as safe assets.

\section{Financial stability, capital requirements}

Before the impact of sustainable financial products on financial system is discussed in more detail, financial stability needs to be clearly defined. This term became widely used in the final decade of the twentieth century and it was often used interchangeably with banking sector stability [Szczepanska 2008: 20]. M. G. J. Schinasi [2004: 1] defines it as the ability of the financial system to perform its tasks in terms of facilitating transactions, providing access to information that allows risk management and allowing economies to absorb shocks. In that sense, narrowing down the definition scope to the banking sector does not materially affect its meaning. This fact highlights the importance of financial institutions in a modern economy.

Financial stability has become the focus of attention during the global financial crisis of 2008 and the sovereign debt crisis that followed, when solvency of some of the World's largest financial institutions was threatened [Degl'Innocenti et al. 2018: 35-37]. Strong links between financial conglomerates and major exposures to home country's government debt have uncovered substantial gaps in credit institution's loss-absorbing capacity despite the fact that in 2008 the need for prudential supervision over financial institutions was already broadly recognized [Flannery, Giacomini 2015: 235-239].

Internationally accepted standards for financial supervision are issued by the Basel Committee of Banking Supervision (BCBS) that brings together supervisory authorities from the most developed markets of the World [Coleman 2012: 90-93]. In 2008, second edition of the regulatory recommendations set, called Basel Capital Accord (Basel II), was already being implemented, setting the capital requirements and information disclosure standards. As the crisis developed it became clear that neither the rules on capital 
composition and capitalization level, nor data disclosure granularity are sufficient to ensure satisfactory level of loss-absorbing capacity and proper assessment of an institution's risk exposure. It is worth to highlight that Basel II was being criticized on that front already before the crisis emerged [Chofaras 2004: 361-362].

Recommendations scope from the Basel Committee has grown substantially since Basel II - third Accord was published in 2010, followed by another update in 2017. Now, the recommendations provide a detailed guideline on qualification of capital components, which is then used for calculating capital requirements at different levels. Additional requirement in terms of short- and long-term liquidity have been introduced and supervisory authorities have been equipped with tools that allow dynamic adjustment of capital requirement according to the phase of the economic cycle [Grundke, Kühn 2019: 13].

At the time of preparing this article (February 2020) the structure of the BCBSrecommended capital of financial institutions is composed of four layers: Core Tier I capital, Tier I Capital, Tier II Capital and Tier III Capital. Core level includes only the most liquid components, such as paid in capital and retained earnings, while the consecutive layers include less liquid instruments that may not be easily used to cover losses at times of a serious financial shock. The capital requirements, calculated against the related riskexposure are as follows [Bank for International Settlements 2019: 1-2]:

Table 1. Components of regulatory capital under the Basel Capital Accord

\begin{tabular}{|l|l|l|}
\hline Tier I & $\begin{array}{l}\text { Common Equity Tier I } \\
\text { (CET I) }\end{array}$ & $\begin{array}{l}\text { Capital available for immediate loss absorption - common } \\
\text { shares, retained earnings, minority interest }\end{array}$ \\
\cline { 2 - 3 } & Additional Tier I & $\begin{array}{l}\text { Capital components also available for loss-absorption by a } \\
\text { functioning bank, that do not qualify as CET I - e.g. } \\
\text { minority interests and instruments without a maturity date, } \\
\text { such as perpetual bonds. PoNV condition applies. }\end{array}$ \\
\hline Tier II & $\begin{array}{l}\text { Capital that covers the losses incurred after a bank is } \\
\text { declared insolvent - including debt instruments, revaluation } \\
\text { reserves and loan loss provisions. PoNV condition applies. }\end{array}$ \\
\hline
\end{tabular}

Source: Bank for International Settlements, [2019]. 
The abovementioned point of non-viability rule (PoNV) requires all eligible capital components under the Basel Accord to be either convertible to common equity or be written-down, typically following a decision from a regulatory authority. The sum of Tier I and Tier II Capital constitutes the Total Regulatory Capital of a financial institution. The required capital level $(4,5 \%, 6 \%$ and $8 \%$ for CET1, Tier 1 and Total capital respectively) is calculated against financial group's risk exposure reflected by its risk-weighted assets. The weights for different assets are specifically defined under the Accord, often referenced against external credit rating agency's score (under the standard approach) if it is available - examples can be found in table 2 below.

Table 2. Exemplary credit risk weights and specific market risk weights under the Basel Capital Accord

\begin{tabular}{|c|c|c|c|c|c|c|}
\hline Asset type & $\begin{array}{c}\text { AA- and } \\
\text { higher }\end{array}$ & $\begin{array}{c}A+\text { to } \\
A-\end{array}$ & $\begin{array}{c}\mathrm{BBB}+\text { to } \\
\mathrm{BBB}-\end{array}$ & $\mathrm{BB}+$ to $\mathrm{B}-$ & Below B- & Unrated \\
\hline Sovereign debt & $0 \%$ & $20 \%$ & $50 \%$ & $100 \%$ & $150 \%$ & $100 \%$ \\
\hline Corporate claims & $20 \%$ & $50 \%$ & $100 \%$ & $150 \%$ & $150 \%$ & $100 \%$ \\
\hline Past due loans & \multicolumn{6}{|c|}{$\begin{array}{l}\text { - } 150 \% \text { when respective provisions below } 20 \% \text { of the outstanding } \\
\text { debt } \\
100 \% \text { when provisions no less than } 20 \% \text { of the outstanding debt } \\
\text { regulatory authority has the right to lower the weight to } 50 \% \text { if } \\
\text { provisions constitute at least } 50 \% \text { of the outstanding amount. }\end{array}$} \\
\hline $\begin{array}{l}\text { Non-government } \\
\text { issued securities } \\
\text { (specific market } \\
\text { risk) }\end{array}$ & & $\begin{array}{l}8 \% \text { for } \\
12 \% \text { fo } \\
8 \% \text { for }\end{array}$ & $\begin{array}{l}\text { to BB- } \\
\text { ings belov } \\
\text { ated instru }\end{array}$ & B- & & \\
\hline
\end{tabular}

Source: Author's own elaboration based on Basel Committee on Banking Supervision [2019a, 2019b].

Considering the number of conditions that have to be met for different instruments to be recognized as equity components, the treatment of equities with ESG features as capital components of an emitting bank under the Basel Capital Accord is highly debatable and may vary between different jurisdictions. Such situation is justifiable especially when considering that no common definition of sustainable development exists. Reputation loss 
of the issuer, definition or interpretation change of what instruments can be deemed sustainable may result in sudden shifts in value and liquidity even if they were initially treated as safe. For the same reason, proper evaluation of risk associated with ESG investment assets is difficult, therefore potentially affecting the precision of a financial group's capital requirement calculation. As will be discussed in the next section, some of the sustainable instruments issued by 2019 have been awarded high credit ratings, which are then reflected by low capital requirement. The fact that the reputation loss risk is not reflected in standard credit scoring can potentially constitute a major regulatory gap for capital requirements, which may prove to be understated as the sustainable finance markets develop.

As the condition of the financial institutions improved and major economies of the World returned to a growth path, subject of stability slowly loss priority to issues around sustainable growth. Sustainability features of investment assets gained popularity among investors and encouraged financial companies to develop products that would satisfy growing demand. Initially small market for these products could only have negligible impact on credit institution's risk exposure and the related capital requirement, but this can change along with the market size and potentially growing concentration of risk.

\section{Sustainable finance initiatives. Impact on stability}

Interest in investment assets with a sustainability feature is growing and its potential is hard to overestimate. The early 2020 report from European Securities and Markets Authority (ESMA) has already signalled that sustainable finance have led to a structural change on the market in Europe, where ESG instruments have outperformed conventional instruments in terms of offered returns [European Securities and Markets Authority 2020: 33-36]. Nonetheless, as mentioned before, ESMA has also confirmed the existence of barriers to their development in form of inconsistent definitions and the related risk of greenwashing, where certain asset's ESG features is subject to interpretations and therefore questionable. If, however, the trends reported by ESMA continue and a parallel drop in demand for non-sustainable debt instruments is observed, it may become necessary to study the impact of such shift on financial stability as well.

It is worth to underline that although sustainable bonds and other ESG instruments so far remain a fraction of the total value of different financial instruments available, their pace of development cannot be underestimated and the amount of related initiatives is overwhelming. Multiple indices for instruments with ESG features have been developed 
and major institutions such as Solactive, Nasdaq, NYSE or CME Group are now publishing equity indices that help tracking the performance of ESG-evaluated companies. In February 2020 Thomson Reuters data also reported nearly 350 tranches of sustainable loans granted under different loan categories and maturity for a total amount of over 420 billion USD [Thomson Reuters Eikon 2020]. Similarly, 37 sustainable bonds issuers have been identified and a lot more green bonds issuers are being reported by different agencies [Fatin 2019]. One notable thing in this context is the reported high rating of green bonds in the EU (see graph 2 below).

The author believes that the apparent rise of interest in ESG instruments, information disclosure on sustainability features contributes relatively little to the general transparency, especially since the respective criteria are often defined and verified by private companies. Similarly, the composition of indices relies on external ESG scoring. Given that no single definition of sustainable development exists, the composition and comparability of these indices may be questioned.

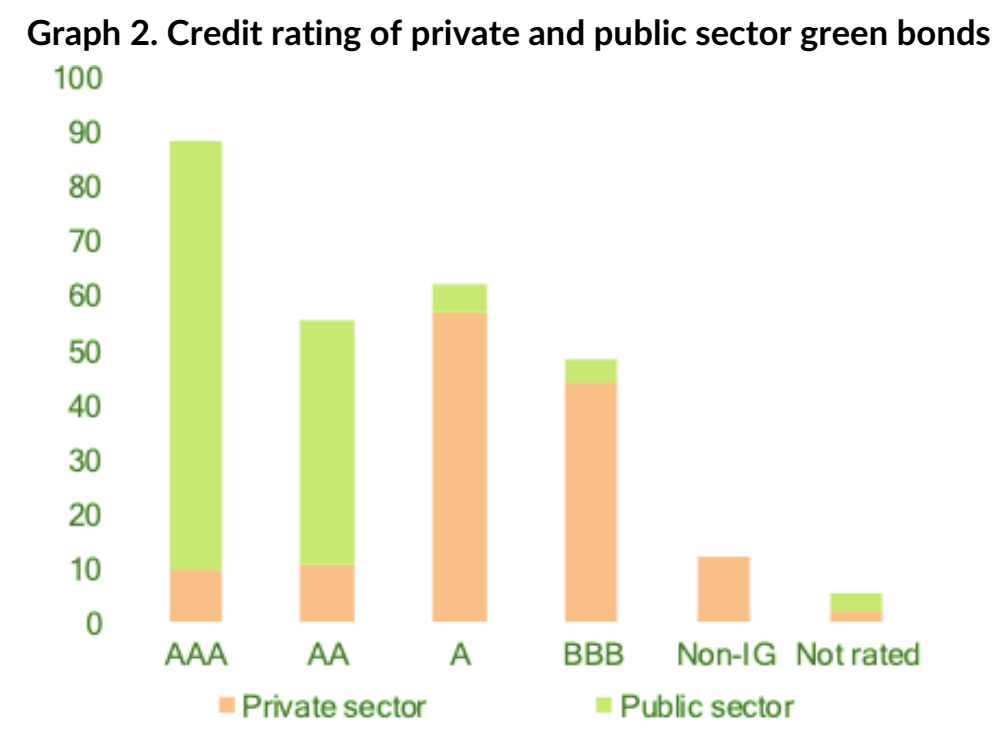

Source: European Securities and Markets Authority [2020].

The challenge for future development of sustainable financial instruments now lies with their qualification as capital components and their assigned risk weight. The ESG feature of these instruments is important to the investors and therefore largely determines their attractiveness. In this context the concerns over the definition of sustainable development effectively translate into an investment risk that can materialize in sudden loss of value due 
to reputation loss (greenwashing) and/or compliance issue, where a given instrument is no longer recognized as an eligible capital component. This can be all the more surprising to the investors, since traditional rating (as shown on graph 1) only consider sustainability in terms of the ability to pay debts. It is worth to highlight, though, that this situation will change over time, since major rating agencies have recognized that rating sustainability features will become an important part of their work in the future [Nauman 2019].

Forward-looking analysis of the potential impact of sustainable finance on financial stability cannot focus on the private sector exclusively. This is not only because public authorities are engaged in issuance of debt instruments with sustainability features, but also because the increasing pressure on ESG considerations has started affecting central bank and regulatory authority policies. Considerations on such matters typically discuss the impact of climate change on financial stability, which is analysed in two aspects: physical - where climate conditions affect existing and future investments financed by the banking sector and transition - where schemes penalizing non-sustainable activities affect the solvency of different business clients of banks [European Securities and Markets Authority 2020: 36]. The author notes that this represents a different approach to the one discussed in this article and essentially focuses on environmental considerations. Supervisory institutions typically study the exposure of the national financial institutions to highly-polluting businesses and the potential impact of insolvency of such debtors on the financial system [Kabza 2019]. The author believes that these are important studies, yet represent only part of the broader picture.

Among the recent initiatives being discussed in the context of central bank's involvement in sustainable development came a proposal to give preference for green bonds under the quantitative easing (QE) programme. QE is the ECB's asset purchasing programme to boost demand in an effort to stimulate economic growth [Todorov 2020: 340-342]. The idea was initially discussed by a consortium of consultants to the European Commission in 2016 on the green bonds investment financing potential [Cochu et al. 2016: 107]. The consultants, however, concluded that this would require reducing the risk weight of green bonds and they would only recommend it as a mid-term solution as the markets for such debt instruments mature. Another unconventional proposal discussing merits to enhance demand for green bonds came from the BCBS, where a suggestion was made to treat green bonds as eligible securities for managing foreign reserves [Fender et al. 2019: 4957]. 
The author believes that the very concept of forcing central banks to prefer environmentally-friendly debt instruments marks a shift in priorities of the financial authorities, where the focus is moving from financial stability towards sustainable finance. The concept is highly controversial, not least because it adds a variable to central bank's decision-making that does not concern its overarching goal of maintaining financial stability [Berger, Kißmer 2013: 109-111]. Furthermore, any sort of preference under the asset purchasing programme goes against its neutrality principle [Andrade et. al. 2016: 712]. Finally, even if these arguments are set aside, additional demand for ESG bonds from central banks substantially affect their price and would further enhance the risk of greenwashing, where the environmental, social or governance features of the debt instruments are properly verified and supervised.

\section{Conclusion}

To conclude, growing popularity of ESG financial instruments has the potential to amass the necessary funding for financing the transition towards a sustainable economy in the future. The attractiveness of these instruments, driven largely by the concerns over climate change around the world, has already inspired many financial institutions to engage into sustainable finance activities. At the same time, different solutions are being proposed to foster the demand even further. The author believes that no single perception of sustainability, combined with a strong pressure on increasing demand for sustainable instruments, may undermine the credibility of sustainable finance initiatives in the future. Global standards and policy measures need to ensure common understanding of what endeavours can be marketed as truly sustainable in order to rule out greenwashing practices.

Until sound business practices around sustainable financial instruments are established, the author would argue against any preferential treatment of such products. The risk of value loss of such instruments either due to reputation loss or a change in underlying definition is so far not factored in their ratings. While this fact should not result in discriminating these products in any way, it should discourage giving it any preference by the central banks, by default operating primarily on safe instruments, as this could lead to potential concentration of the aforementioned risk. The author also notes that substantial increase in demand through the involvement of central banks could also adversely affect the quality of the ESG instruments. 
Finally, considering that the overarching goal of the Basel Capital Accord was to ensure financial stability and standardise the way risk exposure of financial institutions is evaluated, the author believes that reliable quantification of risk associated with reputation loss is necessary. This would both serve the goals of prudential supervision through more adequate assessment of the capital requirements and help safeguarding the integrity of sustainable finance in the long-term.

\section{References}

Andrade P., Breckfelder J., De Fiore F., Karadi P., Tristani O.: The ECB's asset purchase programme: an early assessment, ECB Working Paper Series, Vol. 1956, 2016.

Attenborough T.: Creating a sustainable liquidity management strategy, Available at: https://www.jpmorgan.com/cm/BlobServer/Creating_A_Sustainable_Liquidity_Management Strategy Investment Managers.pdf?blobkey=id\&blobnocache=true\&blobwhere=13205665 59141\&blobheader=application\%2Fpdf\&blobcol=urldata\&blobtable=MungoBlobs, accessed: $27^{\text {th }}$ January 2020.

Barua A., Khatanlar B.: Strong or weak sustainability: a case study of emerging Asia, Asia-Pacific Development Journal, Vol. 22 [1], 2016.

Berger W., Kißmer F.: Central bank independence and financial stability: A tale of perfect harmony?, European Journal of Political Economy, Vol. 31, 2013.

Buckley T.: Over 100 global Financial Institutions Are Exiting Coal, With More to Come, Available at: http://ieefa.org/wp-content/uploads/2019/02/IEEFA-Report 100-and-counting_CoalExitFeb-2019.pdf, accessed: $27^{\text {th }}$ January 2020.

Chofaras D.N.: Economic Capital Allocation with Basel II: Cost, Benefit and Implementation Procedures, Burlington: Elsevier Butterworth-Heinemann, 2004.

Cochu A., Glenting C., Hogg D., Georgiev I., Skolina J. Eisinger F., Jespersen M., Agster R., Fawkes S., Chowdhury T.: Study on the potential of green bond finance for resource-efficient investments, Luxembourg: Publication Office of the European Union, 2016.

Coleman T.C.: Quantitative Risk Management, New Jersey: John Wiley \& Sons Inc., 2012.

De França J., Sandoval W.S.: Necessary and Sufficient Conditions for Liquidity Management, International Journal of Economics and Finance, Vol. 11 [5], 2019.

Degl'Innocenti M., Grant K., Sević A., Tzermes N.G.: Financial Stability, competitiveness and banks' innovation capacity: Evidence from the Global Financial Crisis, International review of Financial Analysis, Vol. 59, 2018.

Dörry S., Schiltz C.: Green financing, interrupted. Potential directions for sustainable finance in Luxembourg, Local Environment. The International Journal of Justice and Sustainability, Vol.23 [7], 2018.

Emas R.: The Concept of Sustainable Development: Definition and Defining Principles, Available at: https://sustainabledevelopment.un.org/content/documents/5839GSDR\%202015 SD conce pt definiton rev.pdf?fbclid=IwAR2A4uB qlwwVFCKBQDRazEuXdwa9cxG5dXMGrTrNfyb7Rx2EER-UnKXVY, accessed: 24th January 2020.

Fatin L.: Green bond issuance tops $\$ 200$ bn milestone - New global record in green finance: Latest Climate Bonds data,

Available at: 
https://www.climatebonds.net/2019/10/green-bond-issuance-tops-200bn-milestone-newglobal-record-green-finance-latest-climate?fbclid=IwAR1WDC9Wyy-TNu8V4KOBfVjGuYi7S2zvjwWryzJ9ykrP8tfnH-liEhqYtM, accessed: 26 January 2020.

Fender I., Sahakyan V., McMorrow M., Zulaica O.: Green bonds: the reserve management perspective, Basel: BIS Quarterly Review, 2019.

Flannery M.J., Giacomini E.: Maintaining adequate bank capital: An empirical analysis of the supervision of European banks, Journal of Banking \& Finance, Vol. 59, 2015.

Grundke P., Kühn A.: The impact of the Basel III liquidity ratios on banks: Evidence from a simulation study, The Quarterly Review of Economics and Finance, 2019.

Hys K., Hawrysz L.: Corporate Social Responsibility Reporting, China-USA Business Review, Vol.11, [11], 2012.

International Finance Corporation, Climate Bonds Initiative: Creating Green Bond Markets - Insight, Innovations, and Tools from Emerging Markets,

Available at:

http://documents.worldbank.org/curated/en/596711540800113453/pdf/131405-WPSBN-Creating-Green-Bond-Markets-Report-2018-PUBLIC.pdf, accessed: 24 $4^{\text {th }}$ January 2020.

Kabza M.: Central banks are increasingly involved in environmental protection,

Available at:

https://www.obserwatorfinansowy.pl/in-english/central-banks-are-increasingly-involved-inenvironmental-protection/, accessed: $24^{\text {th }}$ January 2020.

Klarin T.: The Concept of Sustainable Development: From its Beginning to the Contemporary Issues, Zagreb International Review of Economics \& Business, Vol. 21 [1], 2018.

Nauman B.: Credit rating agencies join battle for ESG supremacy,

Available at:

https://www.ft.com/content/59f60306-d671-11e9-8367-807ebd53ab77, accessed: $24^{\text {th }}$ January 2020.

Pinchot A., Christianson G.: How Are Banks Doing on sustainable Finance Commitments? Not Good Enough,

Available at:

https://www.wri.org/blog/2019/10/how-are-banks-doing-sustainable-financecommitments-not-good-enough, accessed: $26^{\text {th }}$ January 2020.

Schinasi G.J.: Defining Financial Stability, IMF Working Paper, Vol. 04 [187], 2004.

Schoenmaker D., Schramade W.: Principles of Sustainable Finance, Oxford: Oxford University Press, 2019.

Smith P., Sharicz C.A.: The shift needed for sustainability, The Learning Organization, Vol. 18 [1], 2011.

Soppe A.: Sustainable Finance as Connection Between Corporate Social Responsibility and Social Responsible Investing, Indian School of Business WP Indian Management Research Journal, Vol. 1 [3], 2009.

Strandberg C.: Best Practices in Sustainable Finance, Burnaby: Strandberg Consulting, 2005.

Szczepańska O. (2008) Stabilność finansowa jako cel banku centralnego. Studium teoretycznoporównawcze [Financial stability as a central bank goal. Theoretical and comparative study], Warszawa: Wydawnictwo Naukowe Scholar [Scholar Publishing House], 2008.

Todorov K..: Quantify the quantitative easing: Impact on bonds and corporate debt issuance, Journal of Financial Economics, Vol. 135, 2020.

Toman M.A.: The difficulty in defining sustainability, Resources, Vol. 106, 1999.

Urban M.A., Wojcik D.: Dirty Banking: Probing the Gap in Sustainable Finance, Sustainability, Vol. 11 [6], 2019.

Zorlu P.: Transforming the financial system for delivering sustainable development: a high level overview,

Available at:

https://www.iges.or.jp/en/publication_documents/pub/discussionpaper/en/6649/Transform ing+the+financial+system+for+sustainable+development_Oct2018.pdf, accessed: $26^{\text {th }}$ January 2020. 


\section{Other official documents}

Bank for International Settlements : Definition of capital in Basel III - Executive Summary, Available at: https://www.bis.org/fsi/fsisummaries/defcap b3.pdf, accessed: 27 th January 2020.

Basel Committee on Banking Supervision: Calculation of RWA for market risk. Standardised approach, Basel: Bank for International Settlements, 2019a.

Basel Committee on Banking Supervision: Risk-based capital Requirements. Calculation of minimum risk-based capital requirements, Basel: Bank for International Settlements, 2019b.

European Banking Federation: Towards A Green Finance Framework, Available at: https://www.ebf.eu/wp-content/uploads/2017/09/Geen-finance-complete.pdf, accessed: $24^{\text {th }}$ January 2020.

European Securities and Markets Authority: ESMA Report on Trends, Risks and Vulnerabilities, Vol. $1,2020$.

Expert Group on Sustainable Finance: Taxonomy Technical Report, Available at: https://ec.europa.eu/info/sites/info/files/business_economy_euro/banking_and finance/doc uments/190618-sustainable-finance-teg-report-taxonomy en.pdf, accessed: $27^{\text {th }}$ January 2020.

Principles for Responsible Investment: What are the six Principles for Responsible Investment?, Available at: https://www.unpri.org/pri/about-thepri?fbclid=IwAR1VEysQOIMCasJOmY5ODcHRC7rJqu204ZoDbeRPufK_CMIXFz_BOIlxllw, accessed: $26^{\text {th }}$ January 2020.

Task Force on Climate-Related Financial Disclosures: Task Force on Climate-related Financial Disclosures: Status Report, Basel, 2019.

The World Commission on Environment and Development: Report of the World Commission on Environment and Development: Our Common Future,

Available at: https://sustainabledevelopment.un.org/content/documents/5987our-common-future.pdf, accessed: $26^{\text {th }}$ January 2020.

United Nations: Transforming our world: the 2030 Agenda for Sustainable Development, Vol. 70 [1], 2015.

\section{Internet Resources}

Thomson Reuters Eikon: Database, Available at: https://eikon.thomsonreuters.com/index.html, accessed: 26 $6^{\text {th }}$ January 2020. 